\title{
The Impact of Land Conflict on Darmakradenan Toward Social, Economic, and Politic Vulnerability in The Life of Farmers 'Community
}

\author{
W Handoko ${ }^{1}$ \\ ${ }^{1}$ Department of Political Science, Faculty of Social and Political Sciences, Universitas Jenderal \\ Soedirman, Purwokerto
}

Email:waluyo.handoko@unsoed.ac.id

\begin{abstract}
This research is aimed to examine the impact of the Darmakradenan land conflict on the vulnerability of the social, economic and political life of the local farming community. This research is essential because the Darmakradenan conflict has been going on for around 20 years and all the conflict resolution efforts undertaken have not achieved results. This research is qualitative research that selects informants with a purposive method, including farmers, village heads and village officials, management of the farmer group Stan Ampera, plantation managers, community leaders and so on. The results of this research indicated that the two decades of Darmakradenan land conflict had an impact on the vulnerability of social, economic and political life, such as a lack of harmony between farmer groups, loss of livelihoods, tensions between farmer groups and village government, illegal acts, citizens easily ignited to act anarchist and so on. Such conditions have implications for the importance of considering social, economic and political vulnerabilities in developing efforts for real land conflict resolution.
\end{abstract}

Keywords: social, economic, political vulnerability, land conflict

\section{Introduction}

This study is aimed to examine the effects of land conflicts between farmers and the military which have lasted for 20 years and until now a resolution has not been reached. The intended impact is from a social, economic, and political perspective that has plagued farmers' lives for years. The land conflict is in Darmakradenan Village, Banyumas Regency, Central Java Province, Indonesia. The conflict is a conflict between peasants who were members of the Society of Peasants' Mandate (Stan Ampera) and Diponegoro Regional Military Command IV and PT. Rumpun Sari Antan (RSA). This study is expected to fill the gap between previous studies that examined land conflicts, including studies of important factors that can reduce escalation of conflict [1]; studies on land conflict resolution through traditional mechanisms in each community [2]; [3]; studies of the importance of the role of individuals and project managers in conflict resolution efforts [4]; and studies on conflict resolution efforts through traditional justice [5]. In the context of conflict resolution efforts in Indonesia, this study fills in research gaps that have not been reviewed by previous researchers who emphasize conflict resolution efforts based on customary institutions [6]; [7]; resolution efforts that emphasize customary law and Islamic rules [8]; study of the mechanisms of public consultation, negotiation, mediation and arbitration [9];[10]; and studies on conflict resolution efforts that are based on local wisdom [11]. 
The Darmakradenan land conflict began when the Dutch colonial period and continues to the present. At that time the colonial government issued the Wet De Wall Agrariche Act in 1870, where farmers were granted land certificates. The policy for granting land certificates was followed by the application of a high land tax of $30 \%$. The implementation of this policy made farmers unable to pay taxes because it was not comparable to the results obtained from the land business. Facing this problem, the village head at that time suggested that the farmers rent out their land to the capital or foreign owners (Chinese citizens) to pay their tax debt to the colonials.

Entering the official state of Indonesia by changing several regimes, the land settlement has not yet been completed. Although various resolutions have been made starting from negotiations, mediation up to the court has been carried out, but between parties in conflict, namely the farmers and the TNI have not reached an agreement. It shows that there is a gap between theory and empirical (gap between theoretical and empiric). Also, the description of the chronology of land conflicts in Darmakradenan village shows that the land conflict has been very long and cannot be resolved, even though there are regulations that regulate land, namely the Basic Angrarian Law in 1960 (UUPA) in the Old Order and TAP MPR No. IX of 2001 and other regulations governing the land. Thus there is a gap between regulation and empirical facts (gap between regulation and empiric), where normatively regulations regarding land provide an opportunity to resolve the conflict resolution but at the practical level the solution is not finished.

The condition of such land conflicts is an important matter to examine how the impact felt by farmers who have been fighting for their rights for 20 years has undoubtedly consumed energy, time, power, and costs from farmers involved in the conflict. At present many of the lives of Darmakradenan farmers do not get real social, economic and political rights. In this case, the welfare of the Darmakradenan community is at a low level where 1,407 households or $52.62 \%$ are classified as underprivileged and prosperous families. The number of households included in this category consists of 273 households who experience land conflicts. Furthermore, regarding land ownership of the Darmakradenan village community is classified as low; this is because $47.71 \%$ of the people do not own land and farmers who have less than $0.5 \mathrm{Ha}$ of land [12]. The description of the low level of farmer welfare and the lack of land ownership by farmers encourages the importance of studying the impact of land conflicts on the vulnerability of Darmakradenan farmers' wishes in a more comprehensive manner in the social, economic and political fields.

\section{Materials and Methods}

This study uses qualitative methods based on researchers' beliefs based on research experience and the nature of the problem [13]. Qualitative research methods have advantages concerning constructing social reality, cultural meanings, having a focus on interactive processes as well as events, and being flexible in determining research steps [14]. The selection of informants used purposive sampling and snowball sampling techniques [15]. The informants of this study consisted of founder Stan Ampera, chairman, and board of Stan Ampera, farmers, village head of Darmakradenan, head of PT RSA plantation, Darmakradenan village government, Banyumas Regency government, and so on. This study used data collection techniques with a combination of interviews, document studies, and observations [16]. Data processing and analysis started from developing analytical categories and coding data, as an analysis prerequisite [17]. The development of categories and data coding concerned to two things, namely 1 ) ensuring the analytical category was consistent with the research objectives so that the conclusions are valid; 2) balancing to keep too little and too much categorization. The analysis began with the process of clarifying the data to achieve consistency, followed by a theoretical abstraction on information and facts, which produced fundamental statements. By comparing research findings and deepening meaning, continued analysis of data would be obtained simultaneously throughout the research process. 


\section{Results and Discussion}

\subsection{The Land Conflict in Darmakradenan in Historical, Economic and Political Dynamics}

Darmakradenan is a village in Ajibarang Subdistrict, Banyumas Regency, which is classified as beautiful with cocoa and rubber plantations supported by the fertile topography of hilly areas and valleys. However, this beauty is not matched by the welfare of the farmer's life. With a total village area of $1157.86 \mathrm{Ha}$, including $227.65 \mathrm{Ha}$ of disputed land in it, the land beauty and the potential of its territory could not eradicate the poverty of the farmers. Prolonged and unresolved lands conflicts make farmers live in poverty. Official data from the village government shows that out of 3,038 households, the 1707 households (56\%) are low-income families who do not have access to sufficient socio-economic resources. The Darmakradenan community is also a picture of a low-educated population of 5,198 people (57\%) out of 9,050 inhabitants. [18].

The description of their helplessness in accessing social and economic resources can also be seen from a large number of unemployed people, which is as much as $15 \%$ and as farm laborers of $17 \%$ and $1,209(13 \%)$ being farmers. The other $46 \%$ is divided into traders, entrepreneurs, civil servants, etc.[19] Another picture of poverty is the amount of not having a place to live. Families that do not have a home live with other families in one house. Even sometimes one house is occupied by 2-3 families. The well-being of the Darmakradenan community is thus included at a low level, where 1,407 households or $52.62 \%$ belong to low-income families and prosperous families. Table 1 presents the complete level of welfare for the people of Darmakradenan Village.

Table 1. Population Data based on Amount and Welfare Level

\begin{tabular}{|c|c|c|c|}
\hline No. & Categories & Total & Percentage \\
\hline 1 & The number of men & 4,550 & 49.93 \\
\hline 2 & The number of women & 4,562 & 50.07 \\
\hline 3 & The number of heads of families & 2,674 & 100 \\
\hline 4 & Pre-Prosperous Family & 945 & 35.34 \\
\hline 5 & Prosperous Family 1 & 462 & 17.28 \\
\hline 6 & Prosperous Family 2 & 859 & 32.12 \\
\hline 7 & Prosperous Family 3 & 293 & 10.96 \\
\hline 8 & Prosperous Family 3 plus & 115 & 4.3 \\
\hline & Total number & 9,112 & 100 \\
\hline
\end{tabular}

Source: The List of Darmakradenan village potency in 2015, has been processed

Farmers in Darmakradenan Village are poor farmers who expect land ownership status as a source of daily livelihood. They are a group of farmers who have tried all means to fight for the ownership status of $227.65 \mathrm{Ha}$ of plantation land in Darmakradenan Village. The property is believed to be owned by farmers by a message given by their predecessors so that local farmers will continue to care for and develop plantation land. However, after almost twenty years the hopes of the Darmakradenan farmers to own the Darmakradenan plantation land has not come to them.

The origin of the Darmakradenan plantation land dispute is inseparable from the Dutch colonial policy that abolished cultivation in 1870, due to criticism from the European community on Forced Planting which had so much tormented on Indonesian community [20]. After the Forced Planting policy was abolished, the Dutch colonial issued the Agrariche Wet De Wall Act in 1870 which contained the establishment of a policy of granting land certificates to farmers in Indonesia. The policy for granting land certificates was followed by a high land tax assessment of 30 cents per 7000 $\mathrm{m}^{2}$. Of course, the land tax policy maked farmers unable to pay taxes because it was not comparable to the results obtained from land management. In addition to the issue of land tax, the Law also regulated erpacht rights that apply to agricultural land and large plantations, agriculture and small plantations, as well as land for resting and yards. 
The farmers 'objection to the policies of the Dutch colonial government also was felt by farmers in Darmakradenan Village. To overcome this difficulty, in 1892 the head of the village of Darmakradenan at that time, the Village Head of PR, agreed with the farmers to rent Darmakradenan plantation land to Dutch businessmen. The agreement was contained in the letter No. 5 Verponding agreement valid from July $15^{\text {th }}, 1892$ until July $15^{\text {th }}, 1967$, which covered an area of 230.10 Ha with erpacht status. As erpacht land, after July $15^{\text {th }}, 1967$, the land will be returned to the farmers. Since July $15^{\text {th }}, 1892$, the Darmakradenan plantation land was controlled by a Dutch businessman named Jan Abertus van Der Roeft, known as Mr. Maryon and planted with rubber trees. In its development, in 1940 the Dutch businessman transferred the management of plantation land to Chinese entrepreneurs. Since then, the rights to manage the Darmakradenan plantation land have been held successively by Chinese entrepreneurs [21].

But times were changing. The Dutch colonial occupation in Indonesia was not timeless. In 1945, the Indonesian people declared their independence. Along with the independence of the Republic of Indonesia, the Indonesian government through PT Perkebunan Nusantara (PTPN) and the Indonesian State Forest Company (Perhutani) began to nationalize companies previously controlled by the Dutch colonial government. Concerning nationalization, it was also applied to the Darmakradenan plantation. Along with the process of nationalization, when the government established the Agrarian Basic Law of 1960, the giving of the right of erpacht of Dutch businessmen was legally ended, and the Darmakradenan plantation land was under state control.

However, when the darkest political events in the Indonesian political history exploded, namely the rebellion of the Indonesian Communist Party $(P K I)$ in 1965, plantation workers belonging to the Republic of Indonesia Plantation Labor Union (Sarbupri) became one of the organizations linked to the existence of the PKI. In addition to Sarbupri, the Indonesian Farmers' Organization (BTI) organization which consisted of farmers in rural areas was also associated with the PKI rebellion. During these times, many of the plantation workers who worked on the Darmakradenan plantation also became members of Sarbupri, so there was an assumption that they were also involved in supporting the PKI movement in 1965.

The TNI as a state army cleansed PKI supporters from the national level to various rural areas. This situation also affected the situation of workers working on the Darmakradenan plantation. Many workers fled because they were afraid of being accused of being involved in the PKI movement, including in this case Chinese businessmen who rented the plantation land. The Darmakradenan village government under the leadership of the village head at that time also did not dare to accept and manage plantation land. In the end, with reasons for security, the Darmakradenan plantation land was held by the TNI in the territory of Diponegoro Military District Command IV since 1965. What the TNI did at that time was an attempt to deal with the chaotic situation caused by the PKI rebellion, where associated with support for the PKI movement. This means that in this context we can say that the $T N I$ 's control of the Darmakradenan plantation land was preceded by pure action to maintain peace in the form of political stability. In managing plantations, the TNI gave responsibility for plantation management to the Rumpun Diponegoro (Yardip) Foundation. Furthermore, from 1975 until now, Yardip leased Darmakradenan plantation land to PT Rumpun Sari Antan (RSA) [22].

That period was the initial period of the New Order's power that took power from the Old Order in 1966. New Order power grew to become a power that emphasized economic growth and political stability supported by a rigorous security approach. In the practice of New Order power, the penetration of power was felt from the national level to remote areas. Therefore, during the New Order regime, there was almost no effort by farmers who dared to fight for the ownership of the Darmakradenan plantation land. During that time, farmers relied on the limestone mining business, the results of which were very promising because the turnover of money in one month reached 1 billion Indonesian rupiahs. But when the monetary crisis occurred in 1998, the lime business fell; so many farmers who relied on the lime business went bankrupt. Such conditions have increasingly made farmers live in poverty, so farmers are beginning to desire to obtain ownership of plantation 
land managed by PT RSA. For this reason, the following sub-sections present in full the social, economic and political impacts of the life of the farmers of Darmakradenan.

\subsection{The Impact of Land Conflict on Social, Economic and Political Life}

The impact of land conflicts in the social life of farmers or the community can be seen from several perspectives, namely social, economic, and political consequences. The social change of Darmakradenan's farmers after entering 1999 began to appear when the escalation of conflict reached a new phase along with the on-going reform era in Indonesia. The flow of political change at the national level since the fall of the New Order government has spread to rural levels. The life of the Darmakradenan community, which was initially harmonious among fellow citizens, the village government and other government apparatus, began to appear friction. The disharmony of residents was triggered by the existence of a pro-contra against the efforts of some farmers to fight for land rights which at that time was still in the management of PT RSA. That condition led to the existence of two groups with differing views, for those who supported the presence of efforts to struggle the land viewed other groups as "enemies" or vice versa.

In addition to the friction between the community, the disharmony also obvious that Stan Ampera faced the village government. Stan Ampera is an organization formed by farmers as a forum for farmers' struggle in fighting for their rights. They saw that the village government always defended the TNI, which in this case was the party facing Stan Ampera. This was also felt by the Darmakradenan village officers where Stan Ampera considered that the village government was an extension of the TNI. For village government officers themselves, they have admitted that so far concerning land conflicts they have acted following the legal corridors. The legitimate HGU's holder was Diponegoro IV Regional Military Command, so the community saw that village government as part of the TNI. Thus, this land conflict has an impact on society's social change. This condition certainly agrees with Ferguson and John Millar [23], who see that social change can come from conflicting interests with each other.

Other social changes that arise after conflict were changes in people's behavior. A culture of violence and unlawfulness that has not been seen so far, after the conflict was apparent. Courage to commit violence and against the law was seen by carrying out anarchist acts in 1999 by conducting demonstrations by destroying company facilities. In 2014, residents also looted and felled the cocoa plantations owned by PT RSA which reflected selfish behavior and an attitude of arrogance.

Symptoms of violence in people who are experiencing a crisis due to critical change processes, both in the social, economic, political and cultural fields. The phenomenon that occurs in Darmakradenan where people have dared to commit violence and against the law is a situation of community crisis resulting from an important process of change in the economic field. Before the monetary crisis in 1998 the lives of farmers were supported by a very promising limestone business, but due to the financial crisis the limestone business became sluggish, and people lost their livelihoods. This economic situation results in a social change in society.

Regarding the economic perspective, this land conflict can be seen from economic indicators, of course. The indicators intended include the number of poor people in the area of conflict. People who joined Stan Ampera amounted to 325 families initially and now reach 600 families. The number was spread in 4 neighborhood units (RW) in Darmakradenan, namely $R W 6,9,8$, and 10. The data showed that the majority of the poor in the village were concentrated in the four RWs. Conditions in the field showed that in one house there were 2 or 3 households. This condition was not due to the existence of a culture of living together but due to the economic crushed where they cannot afford to own their own homes. This situation can be understood that during the 20 years of conflict, farmers with Stan Ampera in their struggle certainly needed citizen support in the form of material, energy, and mind. Besides, of course, for twenty years faithful farmers demanding the return of land rights were mostly those who only rely on access to the source of life from the land. While with unclear land status, of course, they cannot support their efforts to meet their needs. Thus the concentration of doing an economic enterprise cannot be done well so that economically the members of Stan Ampera did not experience an increase and even the opposite. 
In political life, the condition of citizens who are not in harmony with the village government and economically unlucky certainly has an impact on their political life. One of the essences of politics is citizen participation in decision making concerning them and also related to development affairs in their area. Observing the conditions in the field of disharmony with the village government resulted in the participation of Stan Ampera members in many respects being low. Of course, this is very reasonable considering the relationship between them is not good so that on the one hand the citizens reluctant to take part in the activities of the village government and on the other hand the village government is also very rare to involve them in their activities.

\section{Conclusion}

The Darmakradenan land conflict shows a conflict in which parties face to face structurally lame in terms of political and economic power. The farmers are those who are economically poor and only hope for the existence of land as a source of livelihood. The TNI has a complete set of structures, strengths, and resources to maintain the authority to use plantation land which is indeed legally held by the TNI. However, the structural inequality did not significantly reduce the enthusiasm of farmers to fight for the ownership status of the Darmakradenan plantation land. Both parties have taken various efforts to achieve conflict resolution. However, the actual form of conflict resolution still cannot be achieved to date.

In fact, land conflicts have reduced the rights of farmers to manage land which is their source of income. This means that land conflicts have eroded the rights of farmers to enjoy a prosperous life. The struggle of farmers who have spent energy, time, and material that are widely used by them to fight for land rights also further reduces the rights of farmers to enjoy economic rights to live more properly, neglected farmers' social rights because they focus on the problem of achieving resolution conflict, as well as rights in the political field that are also pawned, and so on.

The study also identifies the impact of conflict from social, economic and political aspects. Socially, the lives of farmers experience a change in the social life order in which disharmony exists among the community members and with the village government. The change in violent behavior and courage to oppose the law is a result of a community crisis caused by an important process of change in the economic field. Loss of livelihoods is a major factor in emerging community crises. The problem of vulnerable economic life also makes prolonged land conflicts and increasingly causes the economic life of the community to not develop. Politically, the relationship between farmers and the village elite is also not harmonious so that farmers' participation in village government activities is too low.

The condition of farmers who are increasingly vulnerable and continue fighting for their rights makes their lives very urgent to be empowered. The hope is that the resolution of the Darmakradenan land conflict will restore the lives of farmers to regain their economic, social and political rights. A further study is needed regarding the model for resolving the Darmakradenan land conflict based on efforts to empower citizens along with the vulnerability of the economic, social and political life of the local farming community.

\section{Acknowledgment}

The author would like to thank the Indonesian Ministry of Research Technology and Higher Education through Dissertation Research Grant 2018.

\section{References}

[1] Ide, Tobias. 2015 "Why do Conflict over Scarce Renewable Resources Turn Violent? A Qualitative Comparative Analysis," Journal of Global Environment Change, Vol. 33.

[2] Emanuel, Maria, and Ndimbwa, Tumpe. 2013 "Traditional Mechanisms of Resolving Conflicts over Land Resource: A Case of Gorowa Community in Northern Tanzania," International Journal of Academic Research in Business and Social Sciences, November, Vol. 3, No. 11, pp.214-224. 
[3] Chanya, Apipalakul, Prachaak, B, Ngang, TK Conflict Management on Use of Watershed Resource, Journal of Procedia-Social and Behavioral Sciences, 136, 2014, h. 481-485.

[4] Prieto-Remona, Thomas, Cobo-Benitab, Jose Ramon, Isabel Ortiz-Marcosa, Isabel. 2015. "Conflict Resolution to Project Performance" Journal of Proceeding Social and Behavioral Sciences, Vol. 194.

[5] Froje, John W. 2009. "Traditional Justice and Reconciliation after Violent Conflict: Learning from African," African Journal on Conflict Resolution, Vol. 9 No. 3. pp. 145 - 155.

[6] Sulastriono, 2014. "Resolusi Konflik Pengelolaan Sumber Daya Alam Berbasis Pranata Adat", Jurnal Media Hukum,Vol. 21 No. 2 December, p.213-224.

[7] Enggelina Iku, Maria, 2010. Peran Lembaga Adat Mosalaki dalam Penyelesaian Konflik Hak Tanah Ulayat di Kelurahan Wolojito Kecamatan Wolojito Kabupaten Ende Provinsi Nusa Tenggara Timur, Tesis, Universitas Gadjah Mada, Yogyakarta.

[8] Syam, Aliar, 2015. Model Resolusi Sengketa Tanah Hak Ulayat dengan Asas Kepastian Hukum dalam Mewujudkan Kesejahteraan Masyarakat Adat di Kabupaten Kampar Propinsi Riau, Disertasi Pascasarjana Unisba Bandung.

[9] Musdalifah, 2007. Konflik Agraria dalam Relasi Antara Perusahan Perkebunan dengan Masyarakat (Kasus Konflik antara Petani dengan PT Lonsum di Kabupaten Bulukamba), Disertasi, Universitas Hasanuddin.

[10] Alting, Husen, 2013. "Konflik Penguasaan Tanah di Maluku Utara: Rakyat Versus Penguasa dan Pengusaha." Jurnal Dinamika Hukum, Vol. 13, No. 2, pp. 266 - 282.

[11] Asmara, Galang, Arba, Maladi, Yadi. 2010 "Resolusi Konflik Pertanahan Berbasis Nilai-nilai Kearifan Lokal di Nusa Tenggara Barat”, Jurnal Mimbar Hukum, Vol. 22. No.1.

[12] Daftar Isian Potensi Desa Darmakradenan 2015, Desa Darmakradenan: Pemerintah Desa Darmakradenan Kecamatan Ajibarang Kabupaten Banyumas.

[13] Strauss, Anslem, and Juliet, Corbin. 1990. Basic of Qualitative Research: Grounded Theory Procedures and Techniques. Beverly Hills, SA: Sage Publications.

[14] Newman, Lawrence, 1994. Social Research Methods: Qualitative and Quantitative Approaches, Boston: Allyn and Bacon.

[15] Harrison, Lisa. 2007. Metodologi Penelitian Politik, Jakarta: Kencana Prenada Media.

[16] Punch, Keith, 2006. Developing Effective Research Proposal, London: Sage Publication.

[17] Silbergh, David M, 2001. Doing Dissertations in Politics: A Student Guide, London: Routledge.

[18] htpp://www.darmakradenan.desa.id diakses 28 Februari 2018.

[19] htpp://www.darmakradenan.desa.id diakses 28 Februari 2018.

[20] Ricklefs, M.C., 2011. Sejarah Indonesia Modern. Yogyakarta: Gadjah Mada University Press.

[21] Laporan Investigasi Kasus Tanah di Darmakradenan, 1999. Desa Darmakradenan : Stan Ampera.

[22] Kronologi Kasus Sengketa Tanah Darmakradenan, 1999. Desa Darmakradenan : Stan Ampera.

[23] Hartanto, Sindung. 2012. Spektrum Teori Sosial Dari Klasik Hingga Posmodern. Jakarta: ArRuzz Media. 